Article

\title{
Fast Degradation of Monochloroacetic Acid by BiOI-Enhanced UV/S(IV) Process: Efficiency and Mechanism
}

\author{
Lili Wang ${ }^{1, *}$ and Xiaowei Liu ${ }^{2,3, *(\mathbb{D})}$ \\ 1 Environmental Engineering, Jiyang College of Zhejiang A \& F University, Zhuji 311800, China \\ 2 Institute of Water Resources \& Ocean Engineering, Ocean College, Zhejiang University, \\ Hangzhou 310058, China \\ 3 Institute of Municipal Engineering, College of Civil Engineering and Architecture, Zhejiang University, \\ Hangzhou 310058, China \\ * Correspondence: liliwang@zafu.edu.cn (L.W.); liuxiaowei@zju.edu.cn (X.L.)
}

Received: 7 April 2019; Accepted: 12 May 2019; Published: 19 May 2019

check for updates

\begin{abstract}
Iodide $\left(\mathrm{I}^{-}\right)$could promote ultraviolet-activated S(IV) processes (UV/S(IV)) and degrade aqueous halogenated organic compounds and hazardous oxoanions. With the interest of promoting use of this technology, this study investigated the feasibility of using bismuth oxyiodide (BiOI) as an $\mathrm{I}^{-}$source to enhance UV/S(IV) where monochloroacetic acid (MCAA) was selected as a testing model compound. Degradation of MCAA by UV/S(IV) increased by $50 \%$ in presence of BiOI. Results of competitive kinetics indicated that the promotion effect brought by BiOI mainly originated from its sustainable release of $\mathrm{I}^{-}$, and subsequent enhanced generation of hydrated electrons. Electron spin resonance detection and fluorescence characterization proved increased formation of sulfite radical, resulting from sulfite oxidation by UV-excited BiOI. However, the sulfite radical only made a small contribution ( $9 \%$ ) to MCAA degradation due to its moderate reactivity toward MCAA $\left(4.2 \times 10^{5} \mathrm{M}^{-1} \cdot \mathrm{s}^{-1}\right)$. UV/S(IV) combined with BiOI significantly decreasing the biotoxicity of MCAA solution. BiOI can be regenerated using $\mathrm{I}^{-}$-containing solution. Our findings provide evidence that $\mathrm{BiOI}$ is a promising $\mathrm{I}^{-}$source and photocatalyst, which progresses the $\mathrm{I}^{-}$-assisted UV/S(IV) process towards practical application.
\end{abstract}

Keywords: bismuth oxyiodide; advanced reduction process; hydrated electron; sulfite radical

\section{Introduction}

Recently, efficient degradation of some halogenated organic compounds (HOCs) and hazardous oxoanions was achieved through UV-activated (bi)sulfite (S(IV)) reduction (abbreviated as $\mathrm{UV} / \mathrm{S}(\mathrm{IV})$ ) [1-3], which is classified as a hydrated electron $\left(\mathrm{e}_{\mathrm{aq}}^{-}\right)$-based advanced reduction process $\left(e_{a q}^{-}-A R P\right)$. However, besides the valid concentration of S(IV) (main precursor of $e_{a q}^{-}$), UV photon absorbance by $\mathrm{S}(\mathrm{IV})$ dominates the production efficiency of $\mathrm{e}_{\mathrm{aq}}^{-}$for this reduction process [4]. The UV sources currently used in water treatment are the low-pressure mercury lamp (UV-L) and medium-pressure mercury lamp (UV-M). UV-L produces light that is almost entirely at $254 \mathrm{~nm}$, and UV-M mainly emits light in the range of 300 to $600 \mathrm{~nm}$ [5]. Hence, a low production efficiency of $\mathrm{e}_{\mathrm{aq}}^{-}$ and a low energy utilization rate are expected when UV-L and UV-M are used to activate S(IV) due to its relatively low absorptivity at wavelength $>250 \mathrm{~nm}$ (Figure 1). As a result, high S(IV) dosage, high $\mathrm{pH}$ (to decrease the proportion of bisulfite), and high power of UV lamp are usually needed to increase $\mathrm{e}_{\mathrm{aq}}^{-}$generation and/or energy utilization for UV/S(IV) process. 


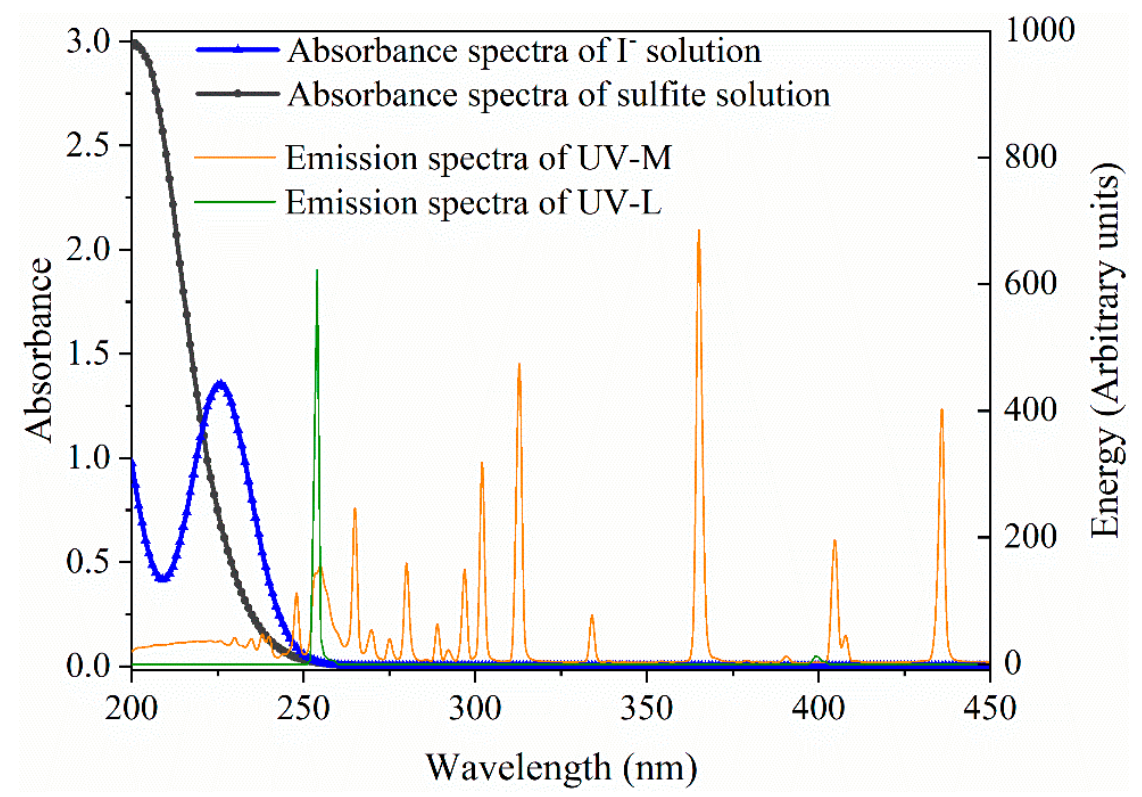

Figure 1. Absorbance spectra of sulfite/iodide $\left(\mathrm{I}^{-}\right)$solution and typical emission spectra of medium-pressure mercury lamp (UV-M)/ low-pressure mercury lamp (UV-L) [6]. Conditions: $\left.[\text { Sulfite }]_{0}=1.0 \mathrm{mM} ; \mathrm{I}^{-}\right]_{0}=100 \mu \mathrm{M} ; \mathrm{pH}=9.0$ for sulfite solution and $\mathrm{pH}=7.0$ for $\mathrm{I}^{-}$solution, $25 \pm 1{ }^{\circ} \mathrm{C}$.

In previous works, Yu et al. [1] and our group [7] tried to introduce iodide $\left(\mathrm{I}^{-}\right)$into UV/S(IV) system $\left(\mathrm{UV} / \mathrm{S}(\mathrm{IV}) / \mathrm{I}^{-}\right)$and observed an enhancement of $\mathrm{e}_{\mathrm{aq}}^{-}$generation. $\mathrm{I}^{-}$was found to play a homogeneous catalyst-like role, and its recycling relies on S(IV) reduction. Nevertheless, as aqueous $\mathrm{I}^{-}$solution also absorbs UV light at wavelength $>250 \mathrm{~nm}$ very weakly (Figure 1), UV/S(IV)/( $\mathrm{I}^{-}$don't perform well enough from the angle of energy utilization and still need to operate under alkaline conditions to guarantee $e_{a q}^{-}$ yield. Moreover, aqueous $\mathrm{I}^{-}$is easy to be oxidized if exposed to air. A possible solution is to replace $\mathrm{I}^{-}$ with a photocatalyst that can simultaneously release $\mathrm{I}^{-}$and absorb wide-range UV light to generate reactive species. Based on this consideration, bismuth oxyiodide (BiOI) may be an ideal candidate. Bismuth oxyiodide, as a semiconductor photocatalyst, has a bandgap energy of $\sim 1.7 \mathrm{eV}$ [8], and thus can be photoexcited by UV/visible light of 200 to $600 \mathrm{~nm}$ [9]. The photocatalytic ability of BiOI was reported to be comparable to or superior to that of commercial $\mathrm{TiO}_{2}$ (P25) [10]. Photoreduction enhancement on the surface of $\mathrm{BiOI}$ is expected in the presence of $\mathrm{S}(\mathrm{IV})$ (as hole scavengers). Furthermore, $\mathrm{BiOI}$ is stable and can release $\mathrm{I}^{-}$slowly in aqueous solution [8], eliminating the concern about deterioration of the $\mathrm{I}^{-}$working solution. Given these facts, we hypothesize that UV/S(IV) combined with BiOI (UV/S(IV)/BiOI) is a promising ARP, which can make full use of UV energy input and meanwhile keep high $e_{a q}^{-}$yield. However, the efficiency and the underlying mechanisms of UV/S(IV)/BiOI for contaminant degradation are totally unknown.

Thus, this study aims to investigate the efficiency and mechanism of UV/S(IV)/BiOI for the decomposition of micropollutants. Monochloroacetic acid (MCAA), due to its simple chemical structure and its distinguishing reactivity toward various radicals, was selected as the model compound to probe the availability of reactive species in the proposed process. The competitive kinetics method, electron spin resonance (ESR) spectroscopy, and fluorescence spectroscopy were used to identify involved reactive species, quantify their contribution, and clarify how BiOI play effectiveness. MCAA degradation products and their biotoxicity were analyzed to evaluate the biocompatibility of treated water. A regeneration test of $\mathrm{BiOI}$ was performed to explore its possible repeated use. 


\section{Results and Discussion}

\subsection{Degradation of MCAA in the UV/S(IV)/BiOI Process}

Figure 2 presents performance of MCAA reduction by UV/S(IV)/BiOI in the presence of dissolved oxygen (DO). The results of MCAA elimination by BiOI adsorption, BiOI/S(IV) adsorption/reduction, UV photolysis, UV/BiOI photocatalytic degradation, and UV/S(IV) reduction are also displayed for comparison. Under current experimental conditions, processes including BiOI adsorption, BiOI/S(IV) adsorption/reduction, UV photolysis, and UV/BiOI, display weak MCAA depletion $(<10 \%)$. Better degradation performance (50\%) was exhibited by UV/S(IV). As expected, the best degradation performance was obtained by UV/S(IV)/BiOI. These results indicate that BiOI adsorption, S(IV) reduction, and UV photolysis played minor roles for MCAA degradation in the UV/S(IV)/BiOI system.

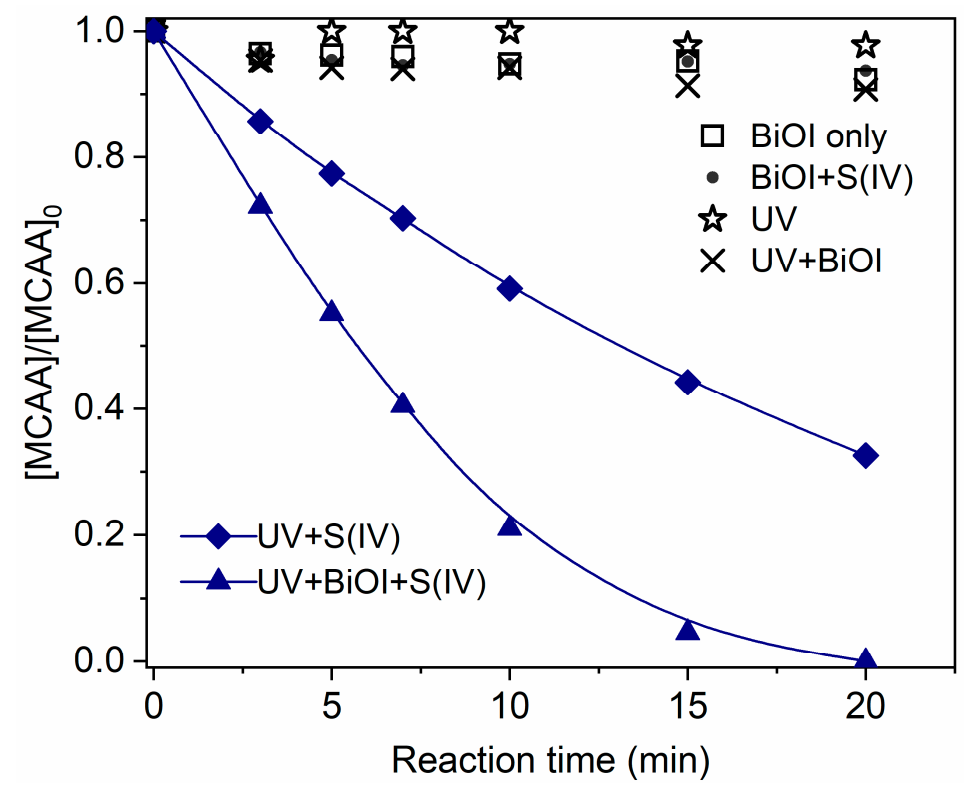

Figure 2. Efficiency of monochloroacetic acid (MCAA) degradation by different processes. Conditions: $[\mathrm{BiOI}]_{0}=1.0 \mathrm{~g} \cdot \mathrm{L}^{-1}\left(84.9 \mu \mathrm{M}\right.$ as I); $[\mathrm{S}(\mathrm{IV})]_{0}=1.0 \mathrm{mM} ;[\mathrm{MCAA}]_{0}=10 \mu \mathrm{M} ;[\mathrm{DO}]_{0}=0.22 \mathrm{mM}\left(7.1 \mathrm{mg} \cdot \mathrm{L}^{-1}\right)$; $\mathrm{pH}=7.0,25 \pm 1^{\circ} \mathrm{C}$.

\subsection{Identification of Main Reactive Species for MCAA Degradation by UV/S(IV)/BiOI}

It has been established that MCAA reduction by UV/S(IV) and UV/S(IV)/I- at $\mathrm{pH} 9.0$ was induced by $\mathrm{e}_{\mathrm{aq}}^{-}$[11]. At neutral $\mathrm{pH}, \mathrm{H}^{\bullet}$ may show increased contribution due to the conversion of $\mathrm{e}_{\mathrm{aq}}^{-}$to $\mathrm{H}^{\bullet}$ $\left(\mathrm{pKa}\left(\mathrm{H}^{\bullet}\right)=9.6[12]\right)$. Recently, several works reported that sulfite radical $\left(\mathrm{SO}_{3}^{\bullet-}\right)$ also played an important role during degradation of organic pollutants by sulfite-mediated processes [13-15]. Addition to unsaturated bond and $\mathrm{H}$-abstraction are the two main reaction types for $\mathrm{SO}_{3}^{\bullet-}$ with organics [16]. In the $\mathrm{UV} / \mathrm{S}(\mathrm{IV}) / \mathrm{BiOI}$ system, $\mathrm{SO}_{3}^{\bullet-}$ can be produced from $\mathrm{UV}$ photolysis of $\mathrm{S}(\mathrm{IV}$ ) (including sulfite $\left(\mathrm{SO}_{3}^{2-}\right)$ and bisulfite $\left.\left(\mathrm{HSO}_{3}^{-}\right)\right)$and reaction of $\mathrm{S}(\mathrm{IV})$ with $\mathrm{e}_{\mathrm{aq}}^{-} / \mathrm{H}^{\bullet}, \mathrm{h}_{\mathrm{VB}}^{+} / \mathrm{HO} \bullet$, and reactive iodine species (RISs) (Equations (1)-(15) [7,14]). Additionally, as no deoxygenation step is taken, photogenerated hole/electron $\left(\mathrm{h}_{\mathrm{VB}}^{+} / \mathrm{e}_{\mathrm{CB}}^{+}\right)$, superoxide radical $\left(\mathrm{O}_{2}^{\bullet-}\right)$, and hydroxyl radical $(\mathrm{HO} \bullet)$ are considered to occur in the UV/S(IV)/BiOI system [17]. Therefore, contributions of $\mathrm{h}_{\mathrm{VB}}^{+} / \mathrm{e}_{\mathrm{CB}^{\prime}}^{-}, \mathrm{O}_{2}^{\bullet-}, \mathrm{HO} \bullet, \mathrm{SO}_{3}^{\bullet-}$, and $\mathrm{e}_{\mathrm{aq}}^{-} / \mathrm{H}^{\bullet}$ are necessary to clarify.

$$
\begin{gathered}
\mathrm{HSO}_{3}^{-} \rightarrow \mathrm{SO}_{3}^{2-}+\mathrm{H}^{+} \\
\mathrm{SO}_{3}^{2-}+\mathrm{hv} \rightarrow \mathrm{SO}_{3}^{\bullet-}+\mathrm{e}_{\mathrm{aq}}^{-} \\
\mathrm{HSO}_{3}^{-}+\mathrm{hv} \rightarrow \mathrm{SO}_{3}^{\bullet-}+\mathrm{H}^{\bullet} \\
\mathrm{H}^{\bullet} \rightarrow \mathrm{e}_{\mathrm{aq}}^{-}+\mathrm{H}^{+}
\end{gathered}
$$




$$
\begin{aligned}
\mathrm{HSO}_{3}^{-}+\mathrm{e}_{\mathrm{aq}}^{-} / \mathrm{H}^{\bullet} & \rightarrow \mathrm{SO}_{3}^{\bullet-}+\mathrm{H}^{\bullet} / \mathrm{H}_{2} \\
\mathrm{SO}_{3}^{2-}+\mathrm{h}_{\mathrm{VB}}^{+} & \rightarrow \mathrm{SO}_{3}^{\bullet-} \\
\mathrm{HSO}_{3}^{-} / \mathrm{SO}_{3}^{2-}+\mathrm{HO} \bullet & \rightarrow \mathrm{SO}_{3}^{\bullet-}+\mathrm{H}_{2} \mathrm{O} / \mathrm{HO}^{-} \\
\mathrm{I}^{-}+\mathrm{hv} & \rightarrow \mathrm{I}^{\bullet}+\mathrm{e}_{\mathrm{aq}}^{-} \\
\mathrm{I}^{\bullet}+\mathrm{I}^{-} & \rightarrow \mathrm{I}_{2}^{-} \\
\mathrm{I}^{\bullet}+\mathrm{I}^{\bullet} & \rightarrow \mathrm{I}_{2} \\
\mathrm{I}^{\bullet}+\mathrm{I}_{2}^{-} & \rightarrow \mathrm{I}_{3}^{-} \\
\mathrm{I}_{2}^{-}+\mathrm{I}_{2}^{-} & \rightarrow \mathrm{I}_{3}^{-}+\mathrm{I}^{-} \\
\mathrm{I}_{2}+\mathrm{I}^{-} & \rightarrow \mathrm{I}_{3}^{-} \\
\mathrm{e}_{\mathrm{aq}}^{-}+\mathrm{I}_{2} & \rightarrow \mathrm{I}_{2}^{-}
\end{aligned}
$$

4-Hydroxytetramethyl-piperidine-1-oxyl (TEMPOL) [18], ethanol (EtOH) [19], triethanolamine (TEA) [20], and 2-methy-2-nitrosopropane (MNSP) [21] were added into the system to quench the in situ-generated $\mathrm{O}_{2}^{\bullet-}, \mathrm{HO} \bullet, \mathrm{h}_{\mathrm{VB}}^{+}$, and $\mathrm{e}_{\mathrm{aq}}^{-}$, respectively. Results reveal that the degradation efficiency almost did not change when TEMPOL, EtOH, and TEA were added, indicating that $\mathrm{O}_{2}^{\bullet-}, \mathrm{HO} \bullet$, and $\mathrm{h}_{\mathrm{VB}}^{+}$played a minor role in the UV/S(IV)/BiOI process. The addition of $\mathrm{S}(\mathrm{IV})$ greatly consumed the dissolved oxygen (Figure 3), thus the generation of $\mathrm{O}_{2}^{--}$from oxygen activation by photogenerated electrons was greatly depressed. S(IV) also consumed $\mathrm{HO} \bullet$ once $\mathrm{HO} \bullet$ formed $\left(\mathrm{k}\left(\mathrm{HO} \bullet+\mathrm{SO}_{3}^{2-}\right)=\right.$ $5.1 \times 10^{9} \mathrm{M}^{-1} \cdot \mathrm{s}^{-1}$ and $\mathrm{k}\left(\mathrm{HO} \bullet+\mathrm{HSO}_{3}^{-}\right)=4.5 \times 10^{9} \mathrm{M}^{-1} \cdot \mathrm{s}^{-1}$ [22] $)$. Given that $\mathrm{e}_{\mathrm{aq}}^{-}$and $\mathrm{H}^{\bullet}$ are conjugated acid-base pairs and showed different reactivity toward MCAA $\left(\mathrm{k}\left(\mathrm{e}_{\mathrm{aq}}^{-}+\mathrm{MCAA}\right)=1.0 \times 10^{9} \mathrm{M}^{-1} \cdot \mathrm{s}^{-1}\right.$; $\left.\mathrm{k}\left(\mathrm{H}^{\bullet}+\mathrm{MCAA}\right)=1.4 \times 10^{6} \mathrm{M}^{-1} \cdot \mathrm{s}^{-1}\right)$ [11], we can preliminarily judge that $\mathrm{e}_{\mathrm{aq}}^{-}$will outcompete $\mathrm{H}^{\bullet}$ on the basis of MCAA degradation. In the presence of MNSP (scavenger of $\mathrm{e}_{\mathrm{aq}}^{-}$), MCAA degradation in the UV/S(IV)/BiOI system deteriorated to an extent equal to the sum of UV photolysis and S(IV)/BiOI reduction/adsorption. $\mathrm{SO}_{3}^{--}$reacted with MNSP at a rate constant of $4.3 \times 10^{7} \mathrm{M}^{-1} \cdot \mathrm{s}^{-1}$, which was higher than that of $\mathrm{SO}_{3}^{\circ-}$ with MCAA $\left(4.2 \times 10^{5} \mathrm{M}^{-1} \cdot \mathrm{s}^{-1}\right.$, Appendix A). Thus, the introduction of MNSP will also shield the reaction of $\mathrm{SO}_{3}^{\bullet-}$ with MCAA. The role of $\mathrm{SO}_{3}^{\cdot-}$ cannot be excluded yet. The position of conduction band of $\mathrm{BiOI}$ is $0.57 \mathrm{~V}$ [23]. Obviously, the reducibility of photogenerated $\mathrm{e}_{\mathrm{CB}}^{-}$ on the surface of $\mathrm{BiOI}$ was even lower than that of $\mathrm{SO}_{3}^{2-}(-0.94 \mathrm{~V}[7])$, indicating that the role of $\mathrm{e}_{\mathrm{CB}}^{-}$ was negligible. Our previous research indicated that $\mathrm{BiOI}$ showed very weak adsorption of nitrate [24]. Additionally, nitrate reacts with $\mathrm{e}_{\mathrm{aq}}^{-}\left(\mathrm{k}\left(\right.\right.$ Nitrate $\left.+\mathrm{e}_{\mathrm{aq}}^{-}\right)=9.7 \times 10^{9} \mathrm{M}^{-1} \cdot \mathrm{s}^{-1}$, [12] fast but slowly with $\mathrm{SO}_{3}^{\bullet-}\left(\mathrm{E}\left(\mathrm{SO}_{3} / \mathrm{SO}_{3}^{\bullet-}\right)=0.25 \mathrm{~V}[25] ; \mathrm{E}\left(\mathrm{NO}_{3}^{-} / \mathrm{NO}_{2}^{-}\right)=0.01 \mathrm{~V}\right.$ [26] $)$. Based on these two facts, nitrate was used to probe the individual contribution of $\mathrm{e}_{\mathrm{aq}}^{-}$. As shown in Figure 4, $0.4 \mathrm{mM}$ nitrate showed a relatively weaker inhibition than $0.4 \mathrm{mM}$ MNSP ( $9 \%$ difference). Such difference indicated the contribution of $\mathrm{SO}_{3}^{\bullet-}$. In summary, $\mathrm{e}_{\mathrm{aq}}^{-}$plays the key role. Finally, we can calculate the respective contribution of all contributors. The contributions of $\mathrm{e}_{\mathrm{aq}}^{-}$reduction, $\mathrm{SO}_{3}^{\bullet-}$ attack, $\mathrm{S}(\mathrm{IV}) / \mathrm{BiOI}$ adsorption/reduction, and UV photolysis were $79.5 \%, 9.0 \%, 2.3 \%$, and $9.2 \%$, respectively. 


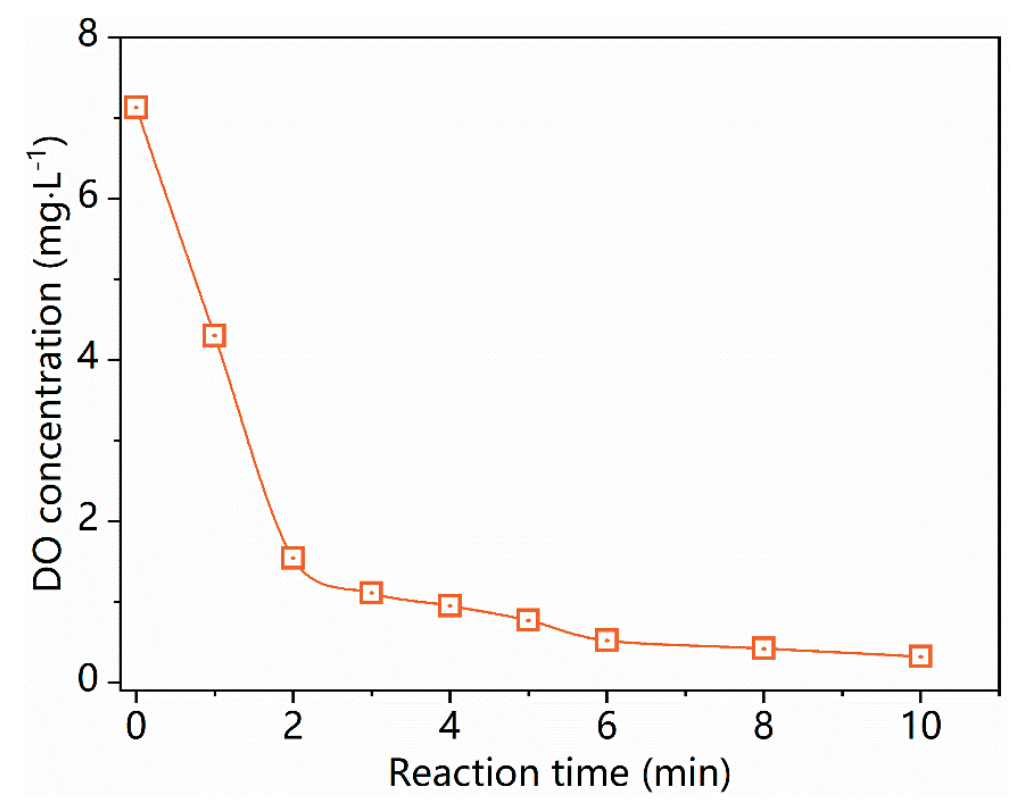

Figure 3. Evolution of dissolved oxygen (DO) concentration during degradation of MCAA by $\mathrm{UV} / \mathrm{S}(\mathrm{IV}) / \mathrm{BiOI}$. Conditions: $[\mathrm{BiOI}]_{0}=1.0 \mathrm{~g} \cdot \mathrm{L}^{-1}\left(84.9 \mu \mathrm{M}\right.$ as I); $[\mathrm{S}(\mathrm{IV})]_{0}=1.0 \mathrm{mM} ;[\mathrm{MCAA}]_{0}=10 \mu \mathrm{M}$; $[\mathrm{DO}]_{0}=7.1 \mathrm{mg} \cdot \mathrm{L}^{-1}(0.22 \mathrm{mM}) ; \mathrm{pH}=7.0,25 \pm 1^{\circ} \mathrm{C}$.

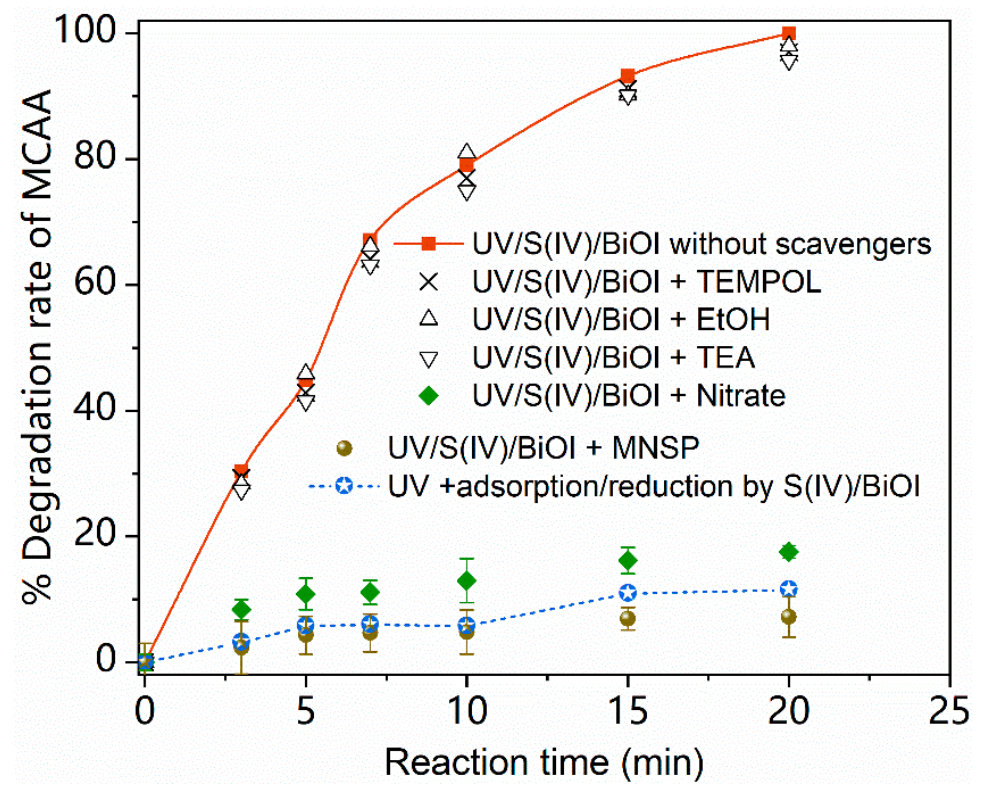

Figure 4. MCAA degradation by ultraviolet-activated S(IV) process combined with $\mathrm{BiOI}(\mathrm{UV} / \mathrm{S}(\mathrm{IV}) / \mathrm{BiOI})$ in the presence of different scavengers. Conditions: $[\mathrm{BiOI}]_{0}=1.0 \mathrm{~g} \cdot \mathrm{L}^{-1}\left(84.9 \mu \mathrm{M}\right.$ as I); $[\mathrm{S}(\mathrm{IV})]_{0}=1.0 \mathrm{mM}$; $[\mathrm{MCAA}]_{0}=10 \mu \mathrm{M}$; the initial concentration of 4-hydroxytetramethyl-piperidine-1-oxyl (TEMPOL), ethanol (EtOH), triethanolamine (TEA), 2-methy-2-nitrosopropane (MNSP) and nitrate is $0.4 \mathrm{mM}$; $[\mathrm{DO}]_{0}=0.22 \mathrm{mM}\left(7.1 \mathrm{mg} \cdot \mathrm{L}^{-1}\right) ; \mathrm{pH}=7.0,25 \pm 1^{\circ} \mathrm{C}$.

\subsection{Role of BiOI in the UV/S(IV)/BiOI System}

As stated above, introduction of BiOI into the UV/S(IV) system greatly enhanced MCAA degradation efficiency ( $50 \%$ increase), and $\mathrm{e}_{\mathrm{aq}}^{-}$was the main contributor. There were two possible pathways for $\mathrm{BiOI}$ to enhance the UV/S(IV) process: (1) BiOI was excited by UV irradiation to generate $\mathrm{h}_{\mathrm{VB}}^{+}, \mathrm{e}_{\mathrm{CB}}^{-}$, and $\mathrm{h}_{\mathrm{VB}}^{+}$oxidized $\mathrm{S}(\mathrm{IV})$ to generate $\mathrm{SO}_{3}^{--}$, and (2) $\mathrm{I}^{-}$releasing from BiOI enhanced the formation of $\mathrm{e}_{\mathrm{aq}}^{-}$. As most of the photogenerated $\mathrm{h}_{\mathrm{VB}}^{+} / \mathrm{e}_{\mathrm{CB}}^{-}$pairs unavoidably recombine at the surface or at bulk trapping sites along with release of photons and heat, leading to fluorescence emission, the 
fluorescence spectra was used to investigate the reaction of $\mathrm{h}_{\mathrm{VB}}^{+}$with $\mathrm{S}$ (IV) on the surface of BiOI. The fluorescence spectra of the BiOI suspension in the presence or absence of S(IV) are shown in Figure 5. For the UV/BiOI system, the spectra exhibited a broad emission band in the range of 350 to $600 \mathrm{~nm}$, which was attributed to luminescence emission from recombination of $\mathrm{h}_{\mathrm{VB}}^{+}$and $\mathrm{e}_{\mathrm{CB}}^{-}$[27]. The presence of S(IV) led to a significant decrease in the emission intensity of the fluorescence spectra, demonstrating that the presence of $\mathrm{S}(\mathrm{IV})$ can effectively reduce recombination rate of photoinduced $\mathrm{h}_{\mathrm{VB}}^{+} / \mathrm{e}_{\mathrm{CB}}^{-}$and lead to an increased charge carrier separation. In addition, we monitored increased spin adduct of $\mathrm{SO}_{3}^{\bullet-}$ with 5,5-Dimethyl-1-pyrroline $\mathrm{N}$-oxide $\left(\mathrm{SO}_{3}^{\bullet-}\right.$-DMPO, Figure 6). The capture of fluorescence emission and increase of $\mathrm{SO}_{3}^{\circ-}$ formation indicated that the first enhancement pathway is important. Note that introduction of $\mathrm{BiOI}$ into UV/S(IV) system promoted formation of $\mathrm{SO}_{3}^{--}$via the reaction of photogenerated $\mathrm{h}_{\mathrm{VB}}^{+}$with $\mathrm{S}(\mathrm{IV})$. However, enhanced formation of $\mathrm{SO}_{3}^{\circ-}$ did not strenthen MCAA degradation due to the low reactivity of $\mathrm{SO}_{3}^{\bullet-}$ towards to MCAA $\left(4.2 \times 10^{5} \mathrm{M}^{-1} \cdot \mathrm{s}^{-1}\right)$.

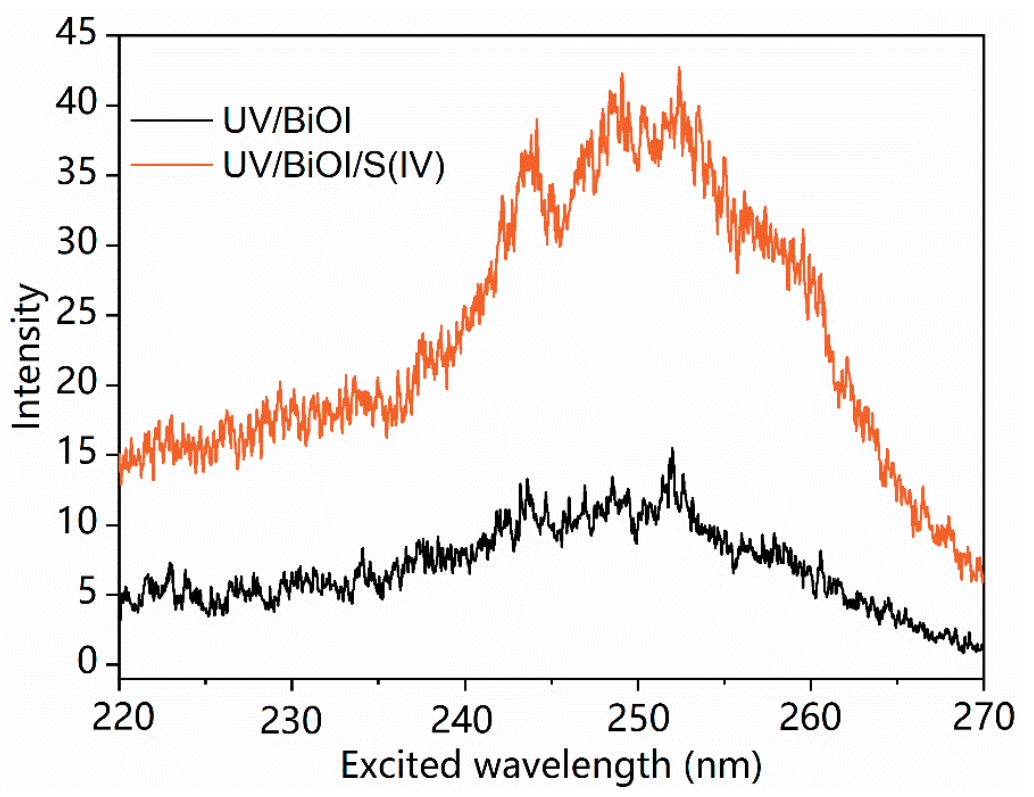

Figure 5. Fluorescence emission spectra for the UV/BiOI and UV/S(IV)/BiOI systems after reaction for $5 \mathrm{~min}$. Conditions: $[\mathrm{BiOI}]_{0}=1.0 \mathrm{~g} \cdot \mathrm{L}^{-1}\left(84.9 \mu \mathrm{M}\right.$ as I); $[\mathrm{S}(\mathrm{IV})]_{0}=1.0 \mathrm{mM}$; $[\mathrm{MCAA}]_{0}=10 \mu \mathrm{M}$; $[\mathrm{DO}]_{0}=0.22 \mathrm{mM}\left(7.1 \mathrm{mg} \cdot \mathrm{L}^{-1}\right) ; \mathrm{pH}=7.0,25 \pm 1^{\circ} \mathrm{C}$.

For the second enhancement pathway, we first monitored $\mathrm{I}^{-}$release in the UV/S(IV)/BiOI process. As shown in Figure 7, the concentration of $\mathrm{I}^{-}$in the reaction solution (free $\mathrm{I}^{-}, \mathrm{I}_{\mathrm{f}}^{-}$) incresed with time. Meanwhile, we observed that iodine contained in BiOI particles $\left(\mathrm{I}_{\mathrm{s}}^{-}\right)$decreased, and the amount of $\mathrm{I}_{\mathrm{s}}^{-}$ decrease was equal to that of $\mathrm{I}_{\mathrm{f}}^{-}$increase. This means there was no loss of releasing $\mathrm{I}^{-}$. This phenomena is consistent with that observed in $\mathrm{UV} / \mathrm{S}(\mathrm{IV}) / \mathrm{I}_{\mathrm{f}}^{-}$[7]. The recycling mechanism of $\mathrm{I}_{\mathrm{f}}^{-}$in $\mathrm{UV} / \mathrm{S}(\mathrm{IV}) / \mathrm{I}_{\mathrm{f}}^{-}$is that RISs, such as $\mathrm{I}^{\bullet}, \mathrm{I}_{2}^{-}$, and $\mathrm{I}_{3}^{-}$, are generated through photoactivation of $\mathrm{I}_{\mathrm{f}}^{-}$and subsequent chain reactions, and are reduced backward to $\mathrm{I}_{\mathrm{f}}^{-}$by S(IV). It has been established that presence of $\mathrm{I}_{\mathrm{f}}^{-}$can greatly enhance the generration of $e_{a q}^{-}$for UV/S(IV) process. To verify the role of sustainable release of $\mathrm{I}^{-}$from $\mathrm{BiOI}$, we simulated the release process of $\mathrm{BiOI}$ through a peristaltic pump dosing system, where $\mathrm{I}_{\mathrm{f}}^{-}$was continuousely added into UV/S(IV) system at a rate nearly equal to that of $\mathrm{I}^{-}$releasing from BiOI. It can be seen from Figure 8 that the degradation curves for the two processes (UV/S(IV)/BiOI and $\mathrm{UV} / \mathrm{S}(\mathrm{IV})$ with continuous $\mathrm{I}_{\mathrm{f}}^{-}$dosing) were very similar ( 10\% difference). Thus, we can conclude that $\mathrm{I}^{-}$releasing from $\mathrm{BiOI}$ is the key enhancement contributor for the UV/S(IV) process. Considering the similar photochemistry of $\mathrm{I}^{-}$in water and in organic solvent along with excellent solubility of (bi)sulfite in mixture of water and organic solvent [28,29], UV/S(IV)/BiOI is believed to efficiently to degrade hazardous HOCs, which are usually treated in organic solvent or mixture of water and organic solvent. 


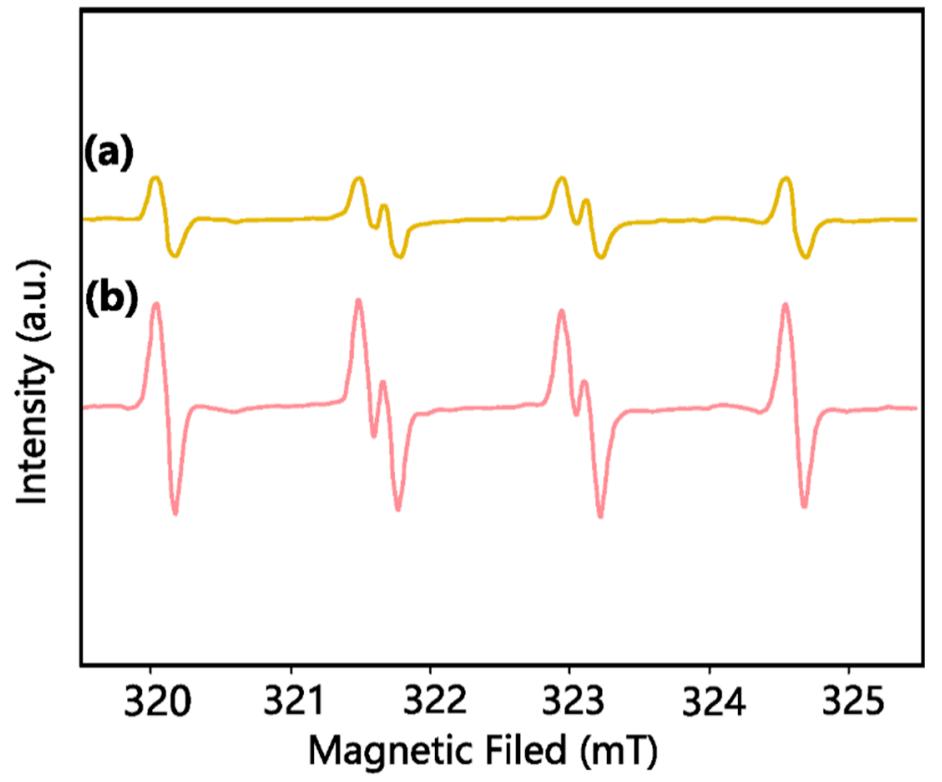

Figure 6. Electron paramagnetic resonance (EPR) spectra for the (a) UV/S(IV) and (b) UV/S(IV)/BiOI systems after reaction for $2 \mathrm{~min}$. Conditions: $[\mathrm{BiOI}]_{0}=1.0 \mathrm{~g} \cdot \mathrm{L}^{-1}\left(84.9 \mu \mathrm{M}\right.$ as I); $[\mathrm{S}(\mathrm{IV})]_{0}=1.0 \mathrm{mM}$; $[\mathrm{MCAA}]_{0}=10 \mu \mathrm{M} ;[\mathrm{DMPO}]_{0}=0.1 \mathrm{mM} ;[\mathrm{DO}]_{0}=0.22 \mathrm{mM}\left(7.1 \mathrm{mg} \cdot \mathrm{L}^{-1}\right) ; \mathrm{pH}=7.0,25 \pm 1^{\circ} \mathrm{C}$.

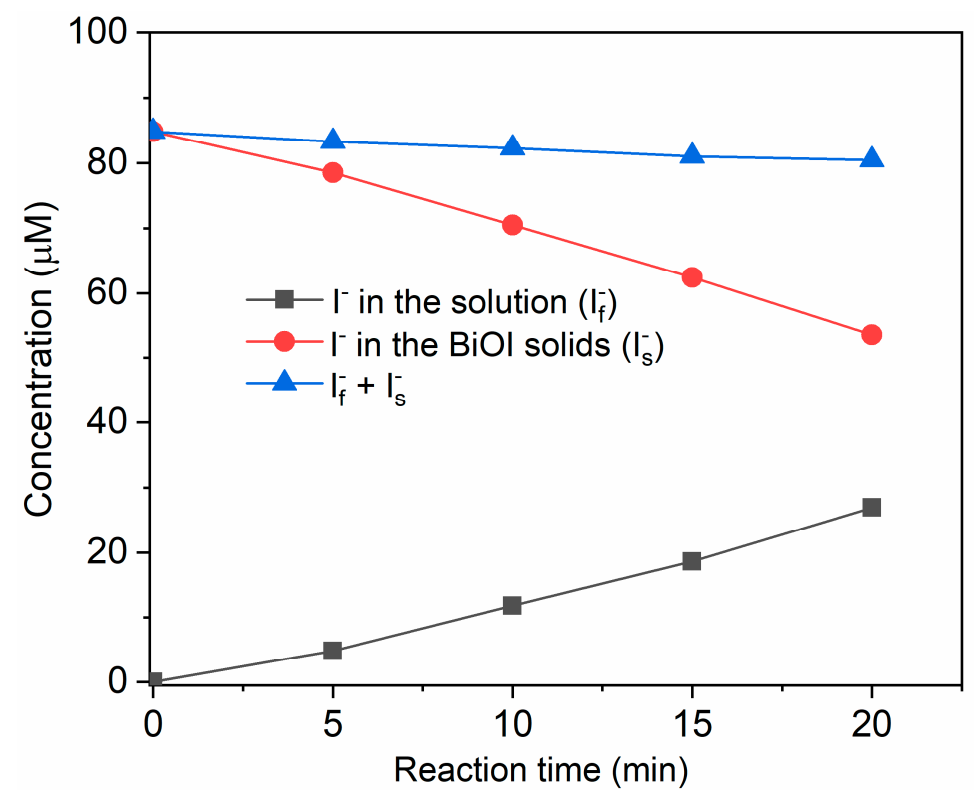

Figure 7. Iodine distribution in the solution and in the BiOI solids during the degradation process. Conditions: $[\mathrm{BiOI}]_{0}=1.0 \mathrm{~g} \cdot \mathrm{L}^{-1}(84.9 \mu \mathrm{M}$ as I $) ;[\mathrm{S}(\mathrm{IV})]_{0}=1.0 \mathrm{mM} ;[\mathrm{MCAA}]_{0}=10 \mu \mathrm{M} ;[\mathrm{DO}]_{0}=0.22 \mathrm{mM}$ $\left(7.1 \mathrm{mg} \cdot \mathrm{L}^{-1}\right) ; \mathrm{pH}=7.0,25 \pm 1{ }^{\circ} \mathrm{C}$. 


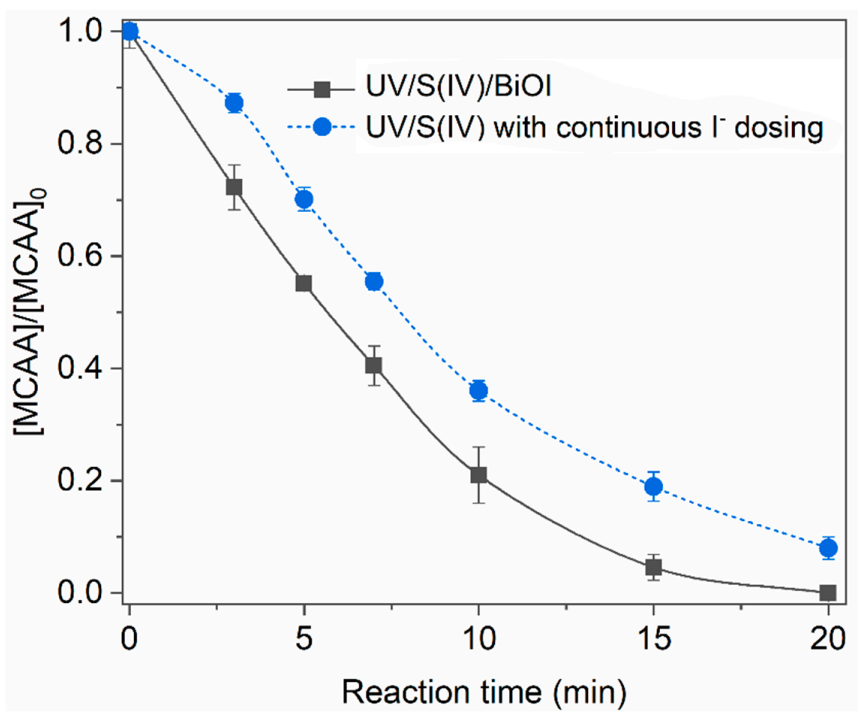

Figure 8. MCAA degradation by UV/S(IV) combined with BiOI or continuous $\mathrm{I}^{-}$addition. Conditions: dosing rate of $\mathrm{I}^{-} 1.28 \mu \mathrm{M} \cdot \mathrm{L}^{-1}$ (approximately equal to the $\mathrm{I}^{-}$releasing rate of $\mathrm{BiOI}$ ); $[\mathrm{BiOI}]_{0}=1.0 \mathrm{~g} \cdot \mathrm{L}^{-1}$ $(84.9 \mu \mathrm{M}$ as I $) ;[\mathrm{S}(\mathrm{IV})]_{0}=1.0 \mathrm{mM} ;[\mathrm{MCAA}]_{0}=10 \mu \mathrm{M} ;[\mathrm{DO}]_{0}=0.22 \mathrm{mM}\left(7.1 \mathrm{mg} \cdot \mathrm{L}^{-1}\right) ; \mathrm{pH}=7.0,25 \pm 1{ }^{\circ} \mathrm{C}$.

\subsection{Degradation Products of MCAA and Biotoxicity of Treated Water}

Based on the results of contribution analysis, $\mathrm{e}_{\mathrm{aq}}^{-}$reduction $(79.5 \%), \mathrm{SO}_{3}^{\bullet-}$ attack $(9.0 \%)$, and UV photolysis $(9.2 \%)$ were confirmed to be involved in the transformation of MCAA. The enhanced formation of $\mathrm{SO}_{3}^{\circ-}$ raises a concern about the generation of organic sulfur-containing products. To shed light on this concern, we checked the loss of inorganic sulfur by determining the concentration variation of inorganic sulfur species during degradation of MCAA (Figure 9). Sulfate $\left(\mathrm{SO}_{4}^{2-}\right)$ was found to be the only product of $\mathrm{S}\left(\mathrm{IV}\right.$ ) (including $\mathrm{SO}_{3}^{2-}$ and $\mathrm{HSO}_{3}^{-}$). This result indirectly proved that there no organic sulfur-containing products generated. To gain more insight, other degradation products of MCAA by UV/S(IV)/BiOI were analyzed. Acetate, formate, succinate, and chloride $\left(\mathrm{Cl}^{-}\right)$were successfully detected (Figure 10). Reports regarding the toxicity evaluation of MCAA solution treated by UV/S(IV)/BiOI demonstrated increasing biocompatibility can be achieved with prolonged treatment time (insert in Figure 10).

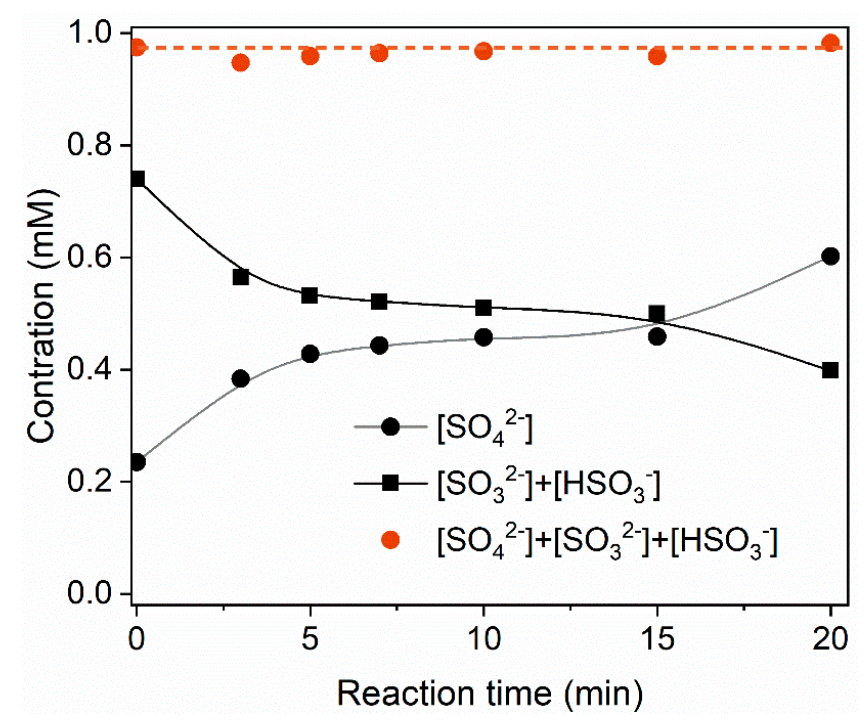

Figure 9. Concentration variation of sulfur species during degradation of MCAA by UV/S(IV) combined with BiOI. Conditions: $[\mathrm{BiOI}]_{0}=1.0 \mathrm{~g} \cdot \mathrm{L}^{-1}\left(84.9 \mu \mathrm{M}\right.$ as I); $[\mathrm{S}(\mathrm{IV})]_{0}=1.0 \mathrm{mM}$; $[\mathrm{MCAA}]_{0}=10 \mu \mathrm{M}$; $[\mathrm{DO}]_{0}=0.22 \mathrm{mM}\left(7.1 \mathrm{mg} \cdot \mathrm{L}^{-1}\right) ; \mathrm{pH}=7.0,25 \pm 1^{\circ} \mathrm{C}$. 


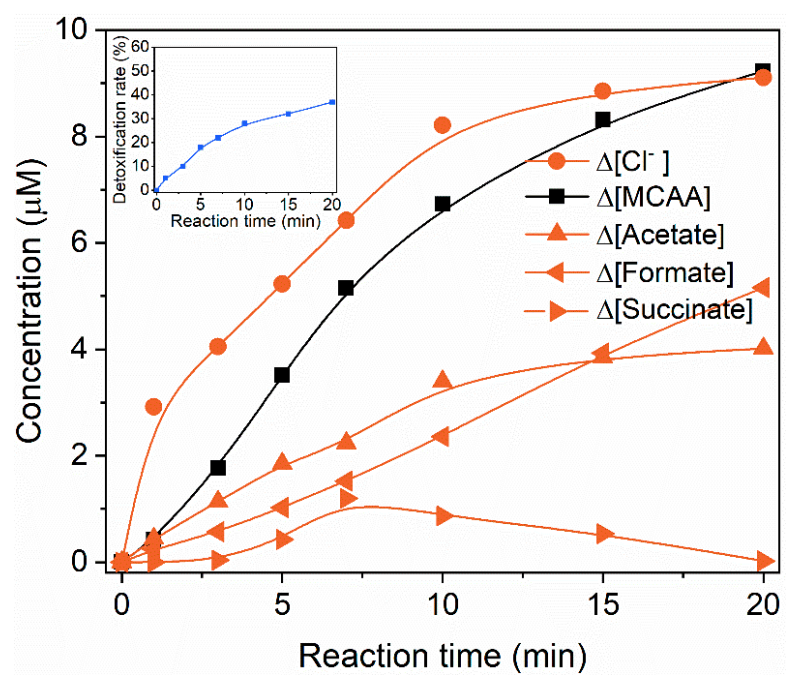

Figure 10. Concentration variation of $M C A A(\triangle[M C A A])$ and its degradation products with an insert showing the detoxification efficiency. Conditions: $[\mathrm{BiOI}]_{0}=1.0 \mathrm{~g} \cdot \mathrm{L}^{-1}\left(84.9 \mu \mathrm{M}\right.$ as I); $[\mathrm{S}(\mathrm{IV})]_{0}=1.0 \mathrm{mM}$; $[\mathrm{MCAA}]_{0}=10 \mu \mathrm{M} ;[\mathrm{DO}]_{0}=0.22 \mathrm{mM}\left(7.1 \mathrm{mg} \cdot \mathrm{L}^{-1}\right) ; \mathrm{pH}=7.0,25 \pm 1{ }^{\circ} \mathrm{C}$.

\subsection{Regeneration of $\mathrm{BiOI}$}

From the discussion above we have learned that BiOI can enhance UV/S(IV) to degrade MCAA through releasing $\mathrm{I}^{-}$at a certain rate. Thus, BiOI faces the problem of iodine loss as a solid carrier of $\mathrm{I}^{-}$with increasing time of use, which will compromise its enhancement effect. So BiOI regeneration test was conducted (Figure 11). Three recycling of BiOI made the 20 min degradation rate of MCAA decrease by $37.4 \%$. However, after regeneration using KI solution, the activity of such a batch of used $\mathrm{BiOI}$ was completely restored. Hence, the activity of $\mathrm{BiOI}$ can be renewed through generation at regular intervals when it was used to enhance UV/S(IV) to degrade pollutants.

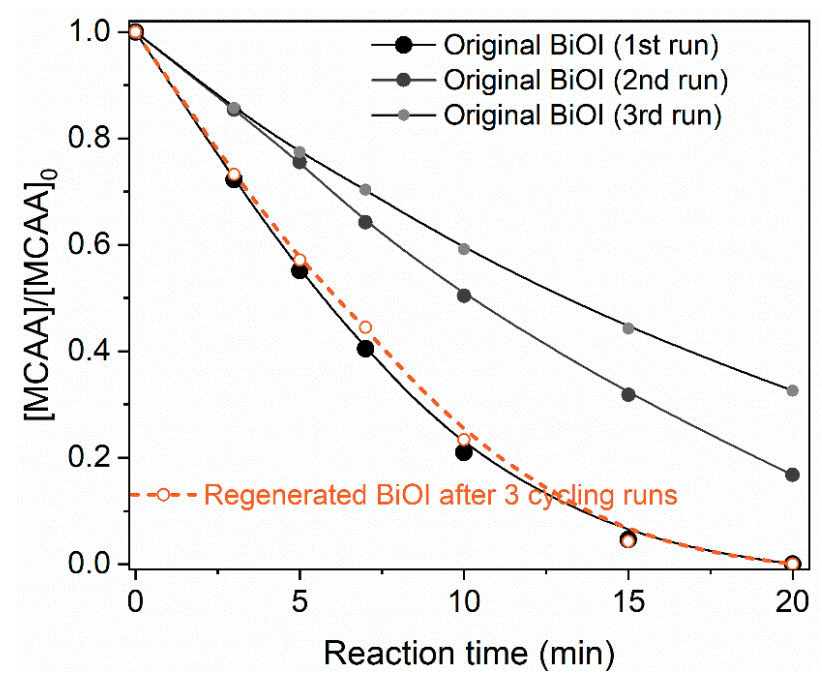

Figure 11. Enhancement effects of BiOI on MCAA degradation by UV/S(IV) in the cycling runs and regeneration test of used BiOI. Conditions: $[\mathrm{BiOI}]_{0}=1.0 \mathrm{~g} \cdot \mathrm{L}^{-1}\left(84.9 \mu \mathrm{M}\right.$ as I); $[\mathrm{S}(\mathrm{IV})]_{0}=1.0 \mathrm{mM}$; $[\mathrm{MCAA}]_{0}=10 \mu \mathrm{M} ;[\mathrm{DO}]_{0}=0.22 \mathrm{mM}\left(7.1 \mathrm{mg} \cdot \mathrm{L}^{-1}\right) ; \mathrm{pH}=7.0,25 \pm 1{ }^{\circ} \mathrm{C}$.

\section{Materials and Methods}

\subsection{Materials and Chemicals}

Sodium sulfite, barium nitrate, potassium iodide, hydrochloric acid, HPLC-grade EtOH, sodium formate, sodium acetate, sodium succinate, and ethylene glycol $\left(\mathrm{C}_{2} \mathrm{H}_{6} \mathrm{O}_{2}\right)$ were all provided by J\&K 
Scientific Ltd. (Shanghai, China). DMPO, TEMPOL, TEA, MNSP, MCAA, and $\mathrm{KNO}_{3}$ were obtained from Sigma-Aldrich (San Francisco, CA, USA). Ultrapure water $(18.2 \mathrm{M} \Omega \cdot \mathrm{cm})$ was used to prepare the tested solutions. $\mathrm{N}_{2} \mathrm{O}(99.99 \%)$ were obtained from Zhejiang Jingong Gas Co. (Hangzhou, China).

\subsection{Synthesis and Characterization of BiOX Microstructures}

The synthesis of BiOI was carried out through a solvothermal procedure [23]. The scanning electron micrograph of sample scanning using a SU-8010 Scanning electron microscope (Hitachi, Japan) indicate that this process yielded BiOI microspheres (Figure 12). X-ray diffraction (XRD) analysis of prepared BiOI specimen was conducted using a Rigaku Dmax-2000 diffractometer using $\mathrm{Cu} \mathrm{K} \alpha$ irradiation at $40 \mathrm{kV}$ and $40 \mathrm{Ma}$ and XRD patterns from $10^{\circ}$ to $80^{\circ} 2 \theta$ were recorded. XRD patterns of the fabricated material were consistent with the six characteristic peaks observed in the standard JCPD card (Figure 13). The specific surface area $\left(64.3 \mathrm{~m}^{2} \cdot \mathrm{g}^{-1}\right)$ was measured using an ASAP2020HD88 analyzer (Micromeritics, USA).

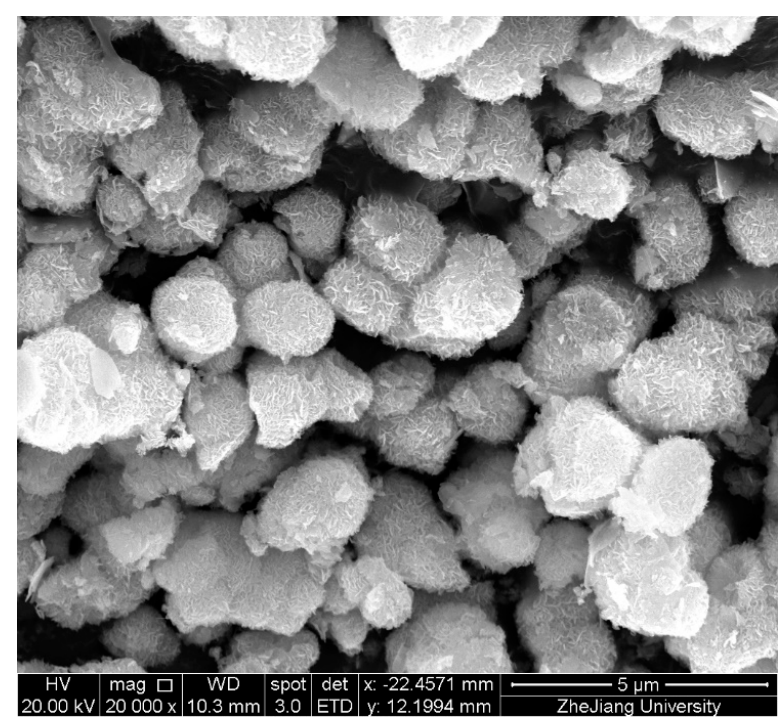

Figure 12. Scanning electron micrograph of prepared BiOI powder.

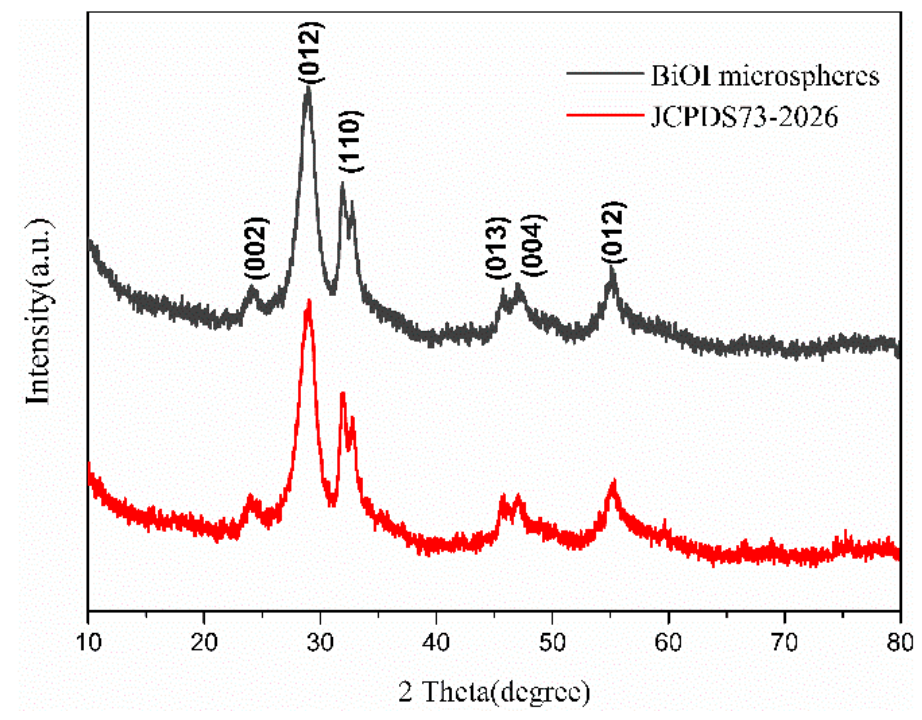

Figure 13. X-ray diffraction patterns of prepared BiOI powder. 


\subsection{Experimental Procedures}

The experiments were performed in a thermostated photoreactor, which has already been reported in our previous work [7]. UV irradiation was generated by a 10W Heraeus low-pressure UV lamp (ozone-free, light centered at $254 \mathrm{~nm}$, Hanau, Germany), and the photoreactor was surrounded by aluminum foil to prevent $U V$ leak and interference of light from environment. The MCAA concentration was set at $10 \mu \mathrm{M}$ and the initial concentration of sulfite $\left(\mathrm{Na}_{2} \mathrm{SO}_{3}\right)$ was kept at $1 \mathrm{mM}$ in the reaction solution. Subsequently, the $\mathrm{pH}$ was adjusted with $10 \mathrm{mM}$ borate buffer (to $\mathrm{pH} 7.4$ ), and $0.10 \mathrm{~g}$ of $\mathrm{BiOI}$ microspheres were dispersed into the $1 \mathrm{~L}$ reaction solution. During the reaction, samples were collected using a syringe at predetermined time intervals and filtered immediately with $0.22 \mu \mathrm{m}$ membrane for analysis of the MCAA concentration. To investigate iodine distribution in aqueous and solid phase during the degradation process, four group experiments were performed, and reactions were quenched (turning off UV lamp and separating BiOI immediately) at 5, 10, 15, and 20 min, respectively. All separated $\mathrm{BiOI}$ particles from the whole $1 \mathrm{~L}$ reaction solution were used to analyze $\mathrm{I}_{\mathrm{s}}^{-}$, and concentration of $\mathrm{I}^{-}$in the bulk solution $\left(\mathrm{I}_{\mathrm{f}}^{-}\right)$was recorded meanwhile.

\subsection{Analytical Methods}

The $\mathrm{pH}$ of reaction solution was measured using a portable $\mathrm{pH}$ meter (Orion 3-Star, Thermo Scientific, MA, USA). MCAA, formate, acetate, succinate, S(IV), and $\mathrm{I}^{-}$were analyzed using ion chromatography (Dionex ICS-2000, Chameleon 6.8, Sunnyvale, CA, USA). Iodide contained in BiOI powders $\left(\mathrm{I}_{\mathrm{S}}^{-}\right)$was extracted using $0.1 \mathrm{M} \mathrm{HCl}$ before analysis. Signals of DMPO-SO ${ }_{3}^{\bullet-}$ adducts $(\mathrm{aN}=14.7 \mathrm{G}$, $\mathrm{a}_{\beta}{ }^{\mathrm{H}}=16.05 \mathrm{G}$ [30]) were recorded using a Bruker E500 Electron Spin Resonance (ESR) spectrometer. Parameter settings: field sweep, $80 \mathrm{G}$; microwave frequency, $9.78 \mathrm{GHz}$; microwave power, $25 \mathrm{~mW}$; modulation amplitude, $0.5 \mathrm{G}$; conversion time, $164 \mathrm{~ms}$; time constant, $164 \mathrm{~ms}$; and receiver gain, $5 \times 10^{4}$. Photoluminescence spectroscopy analysis of BiOI was performed in a Shimadzu RF-6000 fluorophotometer (Shanghai, China).

The toxicity tests were performed on a Microtox model 500 and followed the standard Microtox procedure outlined in the Microtox system operating manual. Water samples were pretreated with membrane filtration to remove BiOI particles. The measurements of light output were carried out after 15 minutes using the $81.9 \%$ screening test method. The toxicity was recorded as the light inhibition rate, which was calculated using Equation (16).

$$
\text { Detoxification rate }(\%)=\frac{\mathrm{T}_{0}-\mathrm{T}_{\mathrm{t}}}{\mathrm{T}_{0}}
$$

where $T_{0}$ and $T_{t}$ are the toxicity of water sample at reaction time $0 \mathrm{~min}$ and $t \mathrm{~min}$, respectively.

\subsection{Determination of Reaction Rate Constant of $\mathrm{SO}_{3}^{\bullet-}$ with $\mathrm{MCAA}$}

For experiments in neutral solution, equimolar amounts of $\mathrm{Na}_{2} \mathrm{SO}_{3}$ and $\mathrm{NaHSO}_{3}$ (formed from $\mathrm{Na}_{2} \mathrm{~S}_{2} \mathrm{O}_{5}$ in $\mathrm{H}_{2} \mathrm{O}$ ) were used $\left(\mathrm{pKa}=7.0\right.$ ). The $\mathrm{SO}_{3}^{\circ-}$-dominated system was created in $\mathrm{N}_{2} \mathrm{O}$-saturated sulfite aqueous solution by continuous ultrasonic irradiation. The main reaction equations are shown in Equations (17)-(19).

$$
\begin{gathered}
\mathrm{H}_{2} \mathrm{O} \stackrel{\text { Ultrasonic irradiation }}{\rightarrow} \mathrm{HO} \bullet+\mathrm{H} \bullet \\
\mathrm{N}_{2} \mathrm{O}+\mathrm{H} \bullet \rightarrow \mathrm{HO} \bullet+\mathrm{N}_{2} \\
\mathrm{HSO}_{3}^{-} / \mathrm{SO}_{3}^{2-}+\mathrm{HO} \bullet \rightarrow \mathrm{SO}_{3}^{\bullet-}+\mathrm{H}_{2} \mathrm{O} / \mathrm{OH}^{-}
\end{gathered}
$$

The ultrasonic irradiation was provided by a Biosafer650-92 apparatus $(650 \mathrm{~W}, 20 \mathrm{kHz}$, Shanghai, China). Ultrasonic irradiation experiments were performed in a cylindrical jacketed glass reactor (inside diameter: $8.2 \mathrm{~cm}$; height: $16.5 \mathrm{~cm}$ ) with magnetic stirring. The second-order rate constant of 
$\mathrm{SO}_{3}^{\bullet-}$ with MCAA ( $\left.\left(\mathrm{SO}_{3}^{\bullet-}+\mathrm{MCAA}\right)\right)$ was determined through a competitive kinetics method [31]. Detailed information is shown in Appendix A.

\subsection{Test of BiOI Regeneration}

For a typical recycling run, BiOI particles were separated from reaction solution by filtration with $0.45 \mu \mathrm{m}$ membrane and directly used in the next recycling run. The loss of $\mathrm{BiOI}$ particles due to filtration and transferring was compensated with fresh BiOI particles. When BiOI particles needed regeneration, they were transferred into regenerant $(0.1 \mathrm{M} \mathrm{KI})$. The soaking time was $12 \mathrm{~h}$. After soaking, BiOI particles were recovered by filtration again and dried in vacuum at $60^{\circ} \mathrm{C}$.

\section{Conclusions}

This study examined the promotion effect of BiOI on the UV/S(IV) process using MCAA as model compound. The results of this research indicated that the presence of BiOI can greatly increase MCAA degradation by UV/S(IV). BiOI influenced the degradation efficiency of UV/S(IV) from two aspects: (1) BiOI can be excited by UV irradiation and tends to oxidize $\mathrm{S}(\mathrm{IV})$ to $\mathrm{SO}_{3}^{\bullet-}$, which was a selective radical and showed a moderate reactivity toward MCAA, and (2) BiOI can sustainably release $\mathrm{I}^{-}$ into the bulk solution and the free $\mathrm{I}^{-}\left(\mathrm{I}_{\mathrm{f}}^{-}\right)$enhanced the generation of $\mathrm{e}_{\mathrm{aq}}^{-}$, which is main contributor to MCAA degradation. MCAA solution treated by UV/S(IV)/BiOI showed decreased biotoxicity. Furthermore, expired BiOI can be regenerated using $\mathrm{I}^{-}$-contained solution. Our findings suggest that the use of light energy input for UV/S(IV)/I $\mathrm{I}^{-}$can be improved by replacing free $\mathrm{I}^{-}$with BiOI ("solid" $\left.\mathrm{I}^{-}\right)$. Along with this manipulation, $\mathrm{UV} / \mathrm{S}(\mathrm{IV}) / \mathrm{I}^{-}$process was expected to take a step closer to the actual application due to the stability of BiOI. Overall, this work provided a feasible application method for $\mathrm{UV} / \mathrm{S}(\mathrm{IV}) / \mathrm{I}^{-}$process.

Author Contributions: Conceptualization, L.W. and X.L.; Methodology, X.L.; Validation, L.W.; Formal Analysis, L.W.; Investigation, L.W.; Resources, X.L.; Data Curation, L.W.; Writing-Original Draft Preparation, L.W.; Writing — Review \& Editing, X.L.; Visualization, L.W.; Supervision, X.L.; Project Administration, L.W. and X.L.; Funding Acquisition, L.W. and X.L.

Funding: This work was financially supported by the Natural Science Foundation of Zhejiang Province (Grant No. LQ19E080023), Jiyang College of Zhejiang A \& F University (Grant No. JY2015RC001), and the special S\&T project on the treatment and control of water pollution (Grant No. 2017ZX07201-003).

Conflicts of Interest: The authors declare no conflicts of interest.

\section{Appendix A}

For a typical run, the reactor was filled with $200 \mathrm{~mL}$ of aqueous solution containing $0.1 \mathrm{M}$ sulfite, $0.05 \mathrm{M}$ phenol (probe compound), and $10 \mu \mathrm{M}$ MCAA. Finally, the ultrasonic probe providing a power density of $195 \mathrm{~W} \cdot \mathrm{L}^{-1}$ was inserted into the solution at a depth of $5.8 \mathrm{~cm}$ and the solution was irradiated with the mode "work 5s-stop 2s". The solution temperature was kept at $25 \pm 1{ }^{\circ} \mathrm{C}$ by cooling water. $\mathrm{k}\left(\mathrm{SO}_{3}^{\circ-}+\mathrm{MCAA}\right)$ can be calculated using Equation (20). The second-order rate constant

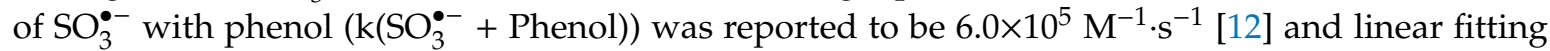
of $\ln [\mathrm{MCAA}] /[\mathrm{MCAA}]_{0} / \ln [\mathrm{Phenol}] /[\mathrm{Phenol}]_{0}$ yield a slope of 0.7 (Figure A1). Finally, the value of $\mathrm{k}\left(\mathrm{SO}_{3}^{\cdot-}+\mathrm{MCAA}\right)\left(4.2 \times 10^{5} \mathrm{M}^{-1} \cdot \mathrm{s}^{-1}\right)$ is obtained.

$$
\mathrm{k}\left(\mathrm{SO}_{3}^{\bullet-}+\mathrm{MCAA}\right)=\mathrm{k}\left(\mathrm{SO}_{3}^{\bullet-}+\mathrm{Phenol}\right) \times\left(\ln [\mathrm{MCAA}] /[\mathrm{MCAA}]_{0} / \ln [\mathrm{Phenol}] /[\mathrm{Phenol}]_{0}\right)
$$




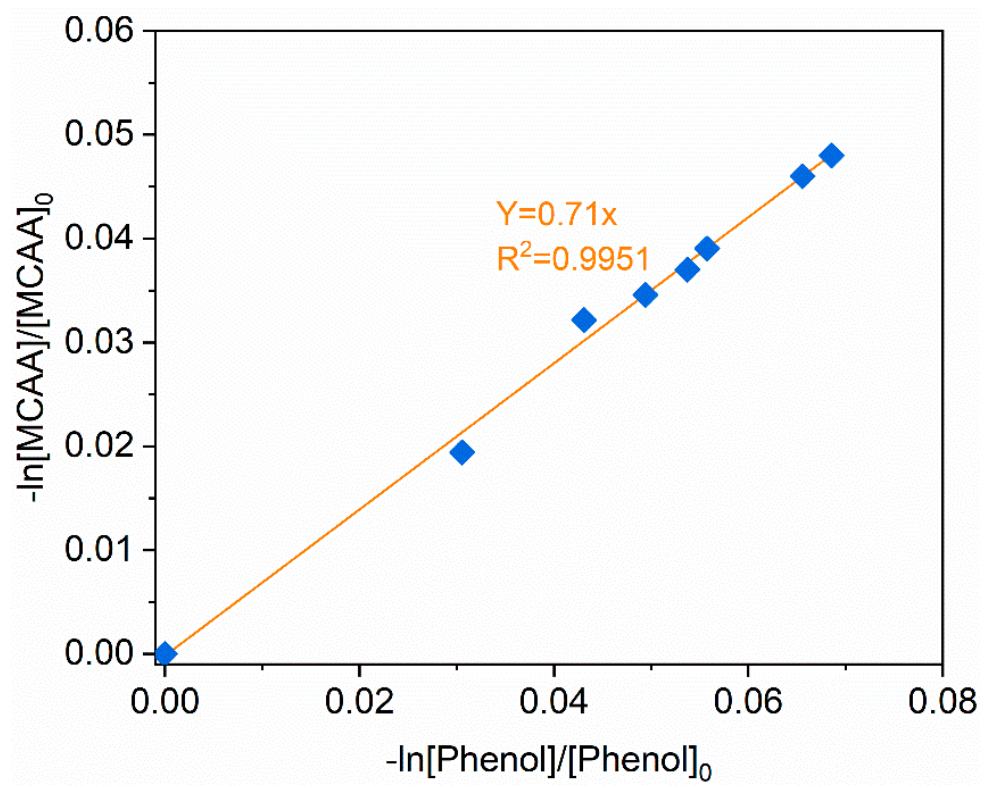

Figure A1. Linear fitting of $-\ln [\mathrm{MCAA}] /[\mathrm{MCAA}]_{0}$ Vs $-\ln [$ Phenol $] /[\text { Phenol }]_{0}$. Conditions: dosing rate of iodide $=1.28 \mu \mathrm{M} \cdot \mathrm{L}^{-1}$ (approximately equal to the iodide releasing rate of $\mathrm{BiOI}$ ); $[\mathrm{Phenol}]_{0}=0.05 \mathrm{M}$; $[\mathrm{S}(\mathrm{IV})]_{0}=0.1 \mathrm{M} ;[\mathrm{MCAA}]_{0}=10 \mu \mathrm{M} ; \mathrm{N}_{2} \mathrm{O}$ saturation; reaction time $10 \mathrm{~min} ; \mathrm{pH}=7.0,25 \pm 1{ }^{\circ} \mathrm{C}$.

\section{References}

1. Yu, K.; Li, X.; Chen, L.; Fang, J.; Chen, H.; Li, Q.; Chi, N.; Ma, J. Mechanism and efficiency of contaminant reduction by hydrated electron in the sulfite/iodide/UV process. Water Res. 2017, 129, 357-364. [CrossRef] [PubMed]

2. Xiao, Q.; Yu, S.; Li, L.; Wang, T.; Liao, X.; Ye, Y. An overview of advanced reduction processes for bromate removal from drinking water: Reducing agents, activation methods, applications and mechanisms. J. Hazard. Mater. 2017, 324, 230-240. [CrossRef] [PubMed]

3. Gu, Y.; Dong, W.; Luo, C.; Liu, T. Efficient reductive decomposition of perfluorooctanesulfonate in a high photon flux UV/sulfite system. Environ. Sci. Technol. 2016, 50, 10554-10561. [CrossRef] [PubMed]

4. Liu, X.W.; Zhang, T.Q.; Wang, L.L.; Shao, Y.; Fang, L. Hydrated electron-based degradation of atenolol in aqueous solution. Chem. Eng. J. 2015, 260, 740-748. [CrossRef]

5. Bensalah, N.; Liu, X.; Abdel-Wahab, A. Bromate reduction by ultraviolet light irradiation using medium pressure lamp. Int. J. Environ. Stud. 2013, 70, 566-582. [CrossRef]

6. Bolton, J.R. Standardization of methods for fluence (UV dose) determination in bench-scale UV experiments. J. Environ. Eng. 2003, 129, 209-215. [CrossRef]

7. Zhang, T.Q.; Wang, J.J.; Yan, D.Y.; Wang, L.L.; Liu, X.W. Efficient reduction of bromate by iodide-assisted $\mathrm{UV} /$ sulfite process. Catalysts 2018, 8, 652. [CrossRef]

8. Zhang, T.; Chu, S.; Li, J.; Wang, L.; Chen, R.; Shao, Y.; Liu, X.; Ye, M. Efficient degradation of aqueous carbamazepine by bismuth oxybromide-activated peroxide oxidation. Catalysts 2017, 7, 315. [CrossRef]

9. Zhang, X.; Ai, Z.; Jia, F.; Zhang, L. Generalized one-pot synthesis, characterization, and photocatalytic activity of hierarchical BiOX $(X=\mathrm{Cl}, \mathrm{Br}, \mathrm{I})$ nanoplate microspheres. J. Phys. Chem. C 2008, 112, 747-753. [CrossRef]

10. Wei, P.; Yang, Q.; Guo, L. Bismuth Oxyhalide Compounds as Photocatalysts. Prog. Chem. 2009, 1734-1741, WOS:000270373000003.

11. Li, X.; Ma, J.; Liu, G.; Fang, J.; Yue, S.; Guan, Y.; Chen, L.; Liu, X. Efficient reductive dechlorination of monochloroacetic acid by sulfite/UV process. Environ. Sci. Technol. 2012, 46, 7342-7349. [CrossRef] [PubMed]

12. Buxton, G.V.; Greenstock, C.L.; Helman, W.P.; Ross, A.B. Critical-review of rate constants for reactions of hydrated electrons, hydrogen-atoms and hydroxyl radicals $\left(\bullet \mathrm{OH} / \bullet \mathrm{O}^{-}\right)$in aqueous-solution. J. Phys. Chem. Ref. Data 1988, 17, 513-886. [CrossRef] 
13. Yazdanbakhsh, A.; Eslami, A.; Moussavi, G.; Rafiee, M.; Sheikhmohammadi, A. Photo-assisted degradation of 2, 4, 6-trichlorophenol by an advanced reduction process based on sulfite anion radical: Degradation, dechlorination and mineralization. Chemosphere 2018, 191, 156-165. [CrossRef] [PubMed]

14. Deng, W.; Zhao, H.; Pan, F.; Feng, X.; Jung, B.; Abdel-Wahab, A.; Batchelor, B.; Li, Y. Visible-light-driven photocatalytic degradation of organic water pollutants promoted by sulfite addition. Environ. Sci. Technol. 2017, 51, 13372-13379. [CrossRef]

15. Cao, J.; Nie, W.; Huang, L.; Ding, Y.; Lv, K.; Tang, H. Photocatalytic activation of sulfite by nitrogen vacancy modified graphitic carbon nitride for efficient degradation of carbamazepine. Appl. Catal. B-Environ. 2019, 241, 18-27. [CrossRef]

16. Erben-Russ, M.; Bors, W.; Winter, R.; Saran, M. The reaction of sulfite anion radical $\left(\mathrm{SO}_{3}{ }^{\bullet-}\right)$ with $^{-1}$ polyunsaturated fatty acids. Int. J. Rad. App. Instr. C. Radiat. Phys. Chem. 1986, 27, 419-424. [CrossRef]

17. Chemseddine, A.; Boehm, H.P. A study of the primary step in the photochemical degradation of acetic acid and chloroacetic acids on a $\mathrm{TiO}_{2}$ photocatalyst. J. Mol. Catal. 1990, 60, 295-311. [CrossRef]

18. Liang, J.; Liu, F.; Li, M.; Liu, W.; Tong, M. Facile synthesis of magnetic $\mathrm{Fe}_{3} \mathrm{O}_{4} @ B i O I @ A g I$ for water decontamination with visible light irradiation: Different mechanisms for different organic pollutants degradation and bacterial disinfection. Water Res. 2018, 137, 120-129. [CrossRef]

19. Xie, P.; Zhang, L.; Chen, J.; Ding, J.; Wan, Y.; Wang, S.; Wang, Z.; Zhou, A.; Ma, J. Enhanced degradation of organic contaminants by zero-valent iron/sulfite process under simulated sunlight irradiation. Water Res. 2019, 149, 169-178. [CrossRef]

20. Jones, W.; Martin, D.J.; Caravaca, A.; Beale, A.M.; Bowker, M.; Maschmeyer, T.; Hartley, G.; Masters, A. A comparison of photocatalytic reforming reactions of methanol and triethanolamine with Pd supported on titania and graphitic carbon nitride. App. Catal B-Environ. 2019, 240, 373-379. [CrossRef]

21. Stefan, M.I. Advanced Oxidation Processes for Water Treatment: Fundamentals and Applications, 1st ed.; IWA Publishing: London, UK, 2017; pp. 125-127. [CrossRef]

22. Huie, R.E.; Neta, P. Rate constants for some oxidations of S(IV) by radicals in aqueous-solutions. Atmos. Environ. 1987, 21, 1743-1747. [CrossRef]

23. Li, Y.; Wang, J.; Yao, H.; Dang, L.; Li, Z. Efficient decomposition of organic compounds and reaction mechanism with BiOI photocatalyst under visible light irradiation. J. Mol. Catal. A-Chem 2011, 334, 116-122. [CrossRef]

24. Li, J.; Sun, S.; Chen, R.; Zhang, T.; Ren, B.; Dionysiou, D.D.; Wu, Z.; Liu, X.; Ye, M. Adsorption behavior and mechanism of ibuprofen onto biocl microspheres with exposed $\{001\}$ facets. Environ. Sci. Pollut. R. 2017, 24, 9556-9565. [CrossRef] [PubMed]

25. Littlejohn, D.; Wang, Y.; Chang, S. Oxidation of aqueous sulfite ion by nitrogen-dioxide. Environ. Sci. Technol. 1993, 27, 2162-2167. [CrossRef]

26. Bard, A.J.; Parsons, R.; Jordan, J. Standard Potentials in Aqueous Solution, 1st ed.; Marcel Dekker: New York, NY, USA, 1985; pp. 127-413. ISBN 0-8247-7291-1.

27. Wang, A.; Li, X.; Zhao, Y.; Wu, W.; Chen, J.; Meng, H. Preparation and characterizations of $\mathrm{Cu}_{2} \mathrm{O} / \mathrm{reduced}$ graphene oxide nanocomposites with high photo-catalytic performances. Powder Technol. 2014, 261, 42-48. [CrossRef]

28. Marrani, A.G.; Bonomo, M.; Dini, D. Adsorption dynamics of redox active species onto polarized surfaces of sensitized nio. ACS Omega 2019, 4, 1690-1699. [CrossRef]

29. Treinin, A.; Hayon, E. Laser photolysis of iodide ions: Spectroscopic evidence for iodine atoms and kinetics of their reaction with iodide in various solvents. Int. J. Radiat. Phys. Ch. 1975, 7, 387-393. [CrossRef]

30. Ranguelova, K.; Rice, A.B.; Khajo, A.; Triquigneaux, M.; Garantziotis, S.; Magliozzo, R.S.; Mason, R.P. Formation of reactive sulfite-derived free radicals by the activation of human neutrophils: An ESR study. Free Radical Bio. Med. 2012, 52, 1264-1271. [CrossRef]

31. Erben-Russ, M.; Michel, C.; Bors, W.; Saran, M. Determination of sulfite radical $\left(\mathrm{SO}_{3}{ }^{--}\right)$reaction rate constants by means of competition kinetics. Radiat. Environ. Bioph. 1987, 26, 289-294. [CrossRef]

(C) 2019 by the authors. Licensee MDPI, Basel, Switzerland. This article is an open access article distributed under the terms and conditions of the Creative Commons Attribution (CC BY) license (http://creativecommons.org/licenses/by/4.0/). 